\title{
Hair Trace Elements in Friedreich's Disease
}

\author{
A. Barbeau, M. Roy, S. Paris
}

\begin{abstract}
Concentrations of zinc, copper, manganese, chromium, cobalt and selenium were measured in the hair obtained from subjects with Friedreich's disease, other inherited ataxias and neurological control patients. Althought zinc and copper concentrations were significantly higher in Friedreich than in the two control groups, the mean values for all groups were well within the normal range. No major deficiency in zinc or selenium was demonstrated in Friedreich's disease using the approach. This does not, however, indicate that there is no defect in zinc and selenium metabolism, availability or transport in this disorder.
\end{abstract}

RÉSUMÉ: Nous avons mesuré les concentrations en zinc, cuivre, manganèse, chrome, cobalt et sélénium dans les cheveux de sujets atteints de la maladie de Friedreich, d'ataxies héréditaires autres et de maladies neurologiques diverses. Même si nous avons observé des concentrations de zinc et de cuivre significativement plus hautes chez les cas des Friedreich par rapport aux deux autres groupes, les concentrations moyennes demeurent clairement dans la fourchette normale. Nous n'avons donc pas pû démontrer, par cette approche, une déficience majeure en zinc ou en sélénium dans la maladie de Friedreich. Ceci ne signifie pas, cependant, qu'il n'existe aucun défaut dans le métabolisme, la disponibilité ou le transport du zinc et du sélênium dans cette maladie.

Can. J. Neurol. Sci. 1984; 11:620-622

Trace elements are important in the biology of most enzymatic processes. Essential metals like copper and zinc play major roles in metabolism. This had been suspected since the discovery by Keilin and Mann (1940) that carbonic anhydrase is a zinc metalloenzyme. Disruptions in copper metabolism have since been recognized in hepato-lenticular degeneration (Wilson's disease) and in Menkes' Steely Hair Syndrome (Singh and Bresnan, 1973). Anomalies in zinc metabolism have proved to be more difficult to establish in the field of neurology, despite a number of international meetings and monographs. (Prasad, 1966; Peisach, Aisen and Blumberg, 1966; Pories et al., 1974; Hambidge and Nichols, 1978). Concentrations of the trace elements in the central nervous system are still not well known, although there is evidence that various regions vary in content as they do in function (Donaldson et al., 1973; Höck et al., 1975). The concentration of these metals is also known to vary after the use of certains drugs, such as Levodopa (Barbeau and Pelletier, 1972). There is no agreement yet on the use of urine or hair concentrations of these elements as a reflection of body content, and particularly of CNS content, but this approach has been gaining in popularity (Hambidge, 1980; Laker, 1982). Modern techniques of analytical chemistry, such as flameless atomic absorption spectrophotometry, neutronactivation analysis, and electron microprobe analysis now permit accurate determination of many trace elements at concentrations down to 0.1 parts per million. Blood levels are transient and relate to the supply of elements in the previous hours or days. Hair offers no information on immediate levels, but fixes trace elements, pro- viding a lasting record of levels over the previous few months.

Recent studies from our group have implicated some abnormality in the handling of taurine in Friedreich's disease (Barbeau et al., 1982). Previous studies had postulated a relationship between the metabolism of taurine and that of zinc (Barbeau and Donaldson, 1974). As will be seen in the discussion, previous unpublished studies using neutron activation analysis did not show significant variations in zinc, copper and manganese levels in hair in Friedreich's disease, but these studies were done before strict criteria for the disease were defined (Geoffroy et al., 1976) and, in view of more recent findings, it was thought useful to repeat the study.

\section{SUBJECTS AND METHODS}

Three groups of patients were studied. 12 patients (age $25.9 \pm 1.1$ years) answered to the strict criteria for Friedreich's disease defined by our group (Geoffroy et al., 1976); 12 other patients (age 38.2 \pm 4.7 years) had a variety of other hereditary ataxic disorders: 7 a dominant form of olivo-ponto-cerebellar atrophy, 2 the Charlevoix-Saguenay (Bouchard et al., 1978) form of recessive spastic ataxia, and 3 a slow-progressing, late-onset form of areflexic recessive ataxia; finally 15 subjects (age $54.4 \pm 2.8$ years) with other neurological disorders were used as another control group. 7 had idiopathic Parkinson's disease and 8 amyotrophic lateral sclerosis.

Hair was removed in sufficient quantity from the back of the head, placed in protective envelopes and air-mailed to Doctor's 
Data Inc, West Chicago, where it was analyzed according to ASETL Protocol by Atomic absorption spectrophotometry using an automated procedure (Alder et al., 1976). The following minerals were measured initially: calcium, magnesium, sodium, potassium, copper, zinc, iron, manganese, chromium, cobalt, lithium, molybdenum, barium, gold, silver, tin, antimony, zirconium, lead, arsenic, mercury, cadmium, aluminum, nickel and beryllium. However, because many of these minerals are directly influenced by the state of osmotic balance, by diet, and by unknown other factors which modify rapidly their concentrations from day to day and because many other trace elements are of unknown physiological significance at this time, or are only secondary to a toxic environment, it was decided to restrict our analysis to the following stable mineral elements: copper, zinc, manganese, chromium and cobalt, all of which have been implicated in some way in the pathogenesis or physiology of disease.

Selenium was added because of its postulated role in vitamin E and free radical metabolisms (Lombeck et al., 1978). Statistical analysis were carried out using Student's $\tau$ test.

\section{Results}

The results of these analyses are given in the table. It is seen that all mean values for the six selected trace metals fall within the normal control range, except for hair zinc which is just above this range in Friedreich's disease. The only significant variations between the study groups concern copper and zinc. Copper is significantly higher in Friedreich's ataxia than in the neurological control group $(p<0.02)$ and than in other forms of ataxia $(p<0.05)$. Zinc is only slightly different between Friedreich and the neurological control group $(p<0.05)$. However 5 of the 12 Friedreich's disease patients had values above the normal range. All other comparisons are non significant.

\section{Discussion}

Previous unpublished studies from our department with the cooperation of Drs. D.R. Crapper and S.S. Krishnan of Toronto, using neutron activation analysis of head and pubic hair level in 36 patients with Friedreich's disease, had failed to uncover significant differences in zinc concentrations between the patients (head hair zinc: $917 \pm 40 \mathrm{microgm} / \mathrm{gm}$ dry; pubic hair zinc: $908 \pm 85 \mathrm{microgm} / \mathrm{gm}$ dry) and normal control subjects (head hair: $858 \pm 83 \mathrm{microgm} / \mathrm{gm}$; pubic hair: $784 \pm 131 \mathrm{microgm} / \mathrm{gm}$ ).
Similar negative results were obtained for copper and manganese. The results of the present study substantially confirm and extend these observations, even though slightly higher zinc and copper concentrations were observed in some patients. No correlations could be made between hair zinc levels and age, duration or severity of the illness, treatment modalities or functional state in any of these patients.

Although no major abnormality was uncovered using this approach, the present results should not be interpreted as indicating that there is no defect in copper, zinc, manganese or selenium metabolism in Friedreich's disease, but only that, if present, such defect is not reflected in hair concentrations. Despite the many studies using hair as a tissue of choice for analysis, the present concensus is that, except for toxic metals expected to be found in high concentrations (for example mercury or arsenic) in special conditions (Barbeau, Nantel and Doriot, 1976), it is unlikely that slight physiologic variations of consequence will be reflected in such studies, unless the level of the deficiency is extreme or long-lasting. Too many errors due to the washing procedure, to collection of hair, to hair dyes or sprays and shampoos can modify the results for this approach to be useful except in large, well controlled, population studies. Finally, in many disorders where an anomaly of trace elements has been proven and shown in blood levels, hair analysis has failed to correlate with the blood values. This has been true in Wilson's disease for copper (Martin, 1964) and acrodermatitis enteropathica for zinc (Moynahan, 1975).

In conclusion, the status of zinc metabolism in Friedreich's disease cannot be inferred at the present time from hair zinc analyses with either atomic absorption or neutron activation. If a zinc anomaly exists in that disorder and if it is related to taurine metabolism, other approaches will have to be used. However, no important zinc or selenium deficiency is evident from these studies, as such deficiencies of any duration would be expected to be reflected in the hair concentration of these metals.

It should be stressed, however, that the present study was carried out in patients relatively older than those in other investigations (see Shapcott et al., this issue) and with other methods (atomic absorption VS-spectrophotometry). Homeostatism of trace metals is a dynamic phenomenon and should be so considered. It is thus possible that at certain moments the need for zinc is greater and that, because of an underlying transport defect, a relative deficiency is created in periods of stress. In the normal (metabolic rest) situation, the availability of zinc would be sufficient for most metabolic functions where it is

\begin{tabular}{|c|c|c|c|c|}
\hline Metal & $\begin{array}{c}\text { (in p.p.m.; mean } \pm \text { S.E.M.) } \\
\begin{array}{c}\text { Normal } \\
\text { Control Range }\end{array}\end{array}$ & Friedreich & $\begin{array}{c}\text { Other } \\
\text { Ataxias }\end{array}$ & $\begin{array}{c}\text { Neurological } \\
\text { Controls }\end{array}$ \\
\hline Copper & $11-41$ & $28.2 \pm 5.2^{*}, \dagger$ & $15.4 \pm 2.0$ & $13.4 \pm 2.3$ \\
\hline Zinc & $124-134$ & $191.4 \pm 17.3$ & $154.2 \pm 11.4$ & $139.9 \pm 15.9$ \\
\hline Manganese & $0.27-1.5$ & $0.53 \pm 0.11$ & $0.76 \pm 0.14$ & $0.72 \pm 0.17$ \\
\hline Selenium & $0.16-0.88$ & $0.36 \pm 0.04$ & $0.41 \pm 0.04$ & $0.36 \pm 0.05$ \\
\hline
\end{tabular}

*Different from other ataxias

tDifferent from neurological controls 
required. Such high demand periods exist during the initial periods of brain and spinal cord development and later during puberty. It is of interest that the demands for the amino acids taurine are also very high during the same periods. The link between the two substances, which we first postulated in 1974 (Barbeau and Donaldson, 1974) is thus still very intriguing.

\section{ACKNOWLEDGEMENTS}

The studies carried out in the present paper were supported by a grant from "L'Association Canadienne pour l'Ataxie de Friedreich". Thanks are due to Drs. D.R. Crapper and S.S. Krishnan for the previous studies with neutron activation analysis. The author also thank Mrs. Nicole Guay-Poirier for typing the manuscript.

\section{REFERENCES}

Alder JF, Alger D, Samuel AJ, West TS (1976) The design and development of a multichannel atomic absorption spectrometer for the simultaneous determination of trace metals in hair. Anal Chim Acta, 87: 301-311.

Barbeau A, Donaldson J (1974) Zinc, taurine and epilepsy. Arch Neurol 30: $52-58$

Barbeau A, Melancon S, Huxtable RJ, Lemieux B (1982) Taurine and Friedreich's ataxia: an update. Advances in Exp Med Biol 139: 389-399.

Barbeau A, Nantel A, Dorlot F (1976) Etude sur les effets médicaux et toxicologiques du mercure organique dans le Nord-Ouest québécois. L'Editeur Officiel du Quêbec, pp 1-278.

Barbeau A, Pelletier JP( 1972) Serum zinc levels after chronic Levodopa therapy in Parkinson's disease. Clin Res 20: 948.

Bouchard JP, Barbeau A, Bouchard R, Bouchard RW (1978) Autosomal recessive spastic ataxia of Charlevoix-Saguenay. Can J Neurol Sci 5: 61-69.
Donaldson J, St-Pierre T, Minnich JL, Barbeau A (1973) Determination of $\mathrm{Na}^{+}, \mathrm{K}^{\dagger}, \mathrm{Mg}^{++}, \mathrm{Zn}^{++}$, and $\mathrm{Mn}^{++}$in rat brain regions. Can J Biochem 51: 87-92.

Geoffroy G, Barbeau A, Breton G, Lemieux B, Aubé M, Léger C, Bouchard JP (1976) Clinical description and Roentgenologic evaluation of patients with Friedreich's ataxia. Can J Neurol Sci 3: 279-286.

Hambidge KM (1980) Hair analyses. Pediatr Clin North Am 27: 855-860.

Hambidge KM, Nichols BL (1978) Zinc and copper in clinical medicine. SP Medical \& Scientific Books, New York, pp 1-132.

Höck A, Demmel U, Schicha H, Kasperek K, Feinendegen LE (1975) Trace element concentration in human brain - Activation analysis of cobalt, iron, rubidium, selenium, zinc, chromium, silver, cesium, antimony, and scandium. Brain 98: 49-64.

Keilin D, Mann T (1940) Carbonic anhydrase, purification and nature of the enzyme. Biochem J 34: 1163-1173.

Laker M (1982) On determining trace elements levels in man: the uses of blood and hair. The Lancet 2: 261-262.

Lombeck I, Kasperek K, Harhisch HD, Becker K, Schumann E, Schroter W, Feinendegen LE, Bremer HJ (1978) The selenium state of children. 1I-Selenium content of serum, whole blood, hair and the activity of erythrocyte glutathione peroxidase in dietetically treated patients with phenylketonuria and maple-syrup urine disease. Eur J Pediatr 128: 213-223.

Martin GM (1964) Copper content of hair and nails of normal individuals and of patients with hepatolenticular degeneration. Nature 202: 903-904.

Moynahan EJ (1979) Acrodermatitis enteropathica: a lethal inherited human zinc-deficiency disorder. Lancet 2: 399.

Peisach J, Aisen P, Blumberg WE (1966) eds. The biochemistry of copper. Academic Press, New York, pp 1-588.

Pories WJ, Strain WH, Hsu JM. Woosley RL (1974) eds. Clinical applications of zinc metabolism. Charles C. Thomas, Springfield, III, pp 1-302.

Prasad AS (1966) Zinc metabolism. Charles C. Thomas, Springfield, III, pp 1-459.

Singh LS, Bresnan MJ (1973) Menkes kinky-hair syndrome (trichopoliodystrophy): low copper levels in the blood, hair and urine. Am J Dis Child 125: 572. 